\title{
ERRATUM
}

Alejandro Legaz-Arrese - Mariano González-Carretero

Isaac Lacambra-Blasco

\section{Adaptation of left ventricular morphology to long-term training in sprint- and endurance-trained elite runners}

Published online: 9 March 2006

(C) Springer-Verlag 2006

\section{Eur J Appl Physiol (2005) DOl: 10.1007/s00421-005- \\ 0076-6}

The names of the authors were incorrect in the pdf and $\mathrm{html}$ versions that appeared online. The correct names are:

Alejandro Legaz-Arrese, Mariano González-Carretero, Isaac Lacambra-Blasco

The online version of the original article can be found at http:// dx.doi.org/10.1007/s00421-005-0076-6

A. Legaz-Arrese $(\square)$

Departmento de Fisiatría y Enfermería, Universidad de Zaragoza, C/ Domingo Miral S/N, Zaragoza, 50009, Spain

E-mail: alegaz@unizar.es

E-mail: alegaz@unizar.es

M. González-Carretero · I. Lacambra-Blasco

Division of Cardiology, Echocardiography Laboratory, Clinical

University Hospital, Zaragoza, Spain 